\title{
Synthesis, reactions and pharmacological studies of new series of selenolo [2,3-b]tetrahydroquinoline
}

\author{
Magda H. Abdel-Lattif ${ }^{1,2}$ *, Mohamed I. Kobeasy ${ }^{1,3}$, Shams H. Abdel-Hafez ${ }^{1,4}$ \\ ${ }^{I}$ Taif University, chemistry department, faculty of science, Taif, 21974, Kingdom Saudi Arabia \\ ${ }^{2}$ Medicolegal institute-ministry of justice, Cairo, Egypt \\ ${ }^{3}$ Biochemistry department, Faculty of Agriculture, Cairo University, Cairo, Egypt \\ ${ }^{4}$ Assiut University, chemistry department, faculty of science, Assiut, 71516, Egypt \\ *Corresponding author E-mail: magdah11uk@hotmail.com
}

Copyright $\odot 2014$ Magda H. Abdel-Lattif et al. This is an open access article distributed under the Creative Commons Attribution License, which permits unrestricted use, distribution, and reproduction in any medium, provided the original work is properly cited.

\begin{abstract}
A novel series of selenolo [2, 3-b] tetrahydroquinoline derivatives were synthesized by the reaction of $\mathrm{NaSeH}$ with 2 chloro-3-cyano-4-(4-methoxyphenyl)-5, 6, 7, 8-tetrahydroquinoline 2 followed by reactions with chloro acetone, chloro acetonitrile, ethyl chloroacetate and chloro acetamide to yield 9 and 11a-c respectively. Reactions of 11c with acetic anhydride, cyclohexanone and aromatic aldehyde affording derivatives 12-14 respectively. Spectroscopic (IR, 1HNMR, 13CNMR and MS) were confirmed the structure of the synthesized compounds. Compounds 5a-c, 9, 11a-c, 12, 13 and 14 were investigated for their anti-inflammatory and analgesic activities; in addition, the most active compounds were tested for their acute toxicity.
\end{abstract}

Keywords: Tetrahydro Quinolines; Pharmacological Screening; Pyrimidoselenolo Tetrahydroquinolines; Spirocyclohaxanepyrimidoselenolo Tetrahydroquinoline.

\section{Introduction}

Tetrahydroquinolines are used as a precursor for synthetic many of heterocyclic compounds for examples their use in the synthesis of pyrazolo[3,4-b]quinolines and benzo[b][1,8] naphthyridines derivatives [1-6] which possess antitumor, trypanocidal and DNA binding properties [7,8] and are antimicrobial agents [9]. While pyrazolo[3,4-b]quinoline derivatives are used as pharmaceutical agents and as inhibitors of oncogenic Ras [10,11]. A literature survey indicates that incorporation of a selenium atom in the quinoline nucleus posses' anti-inflammatory and analgesic activities; in addition, pyrimidoselenolo quinoline derivatives were saver concerning ulcerogenicity in animals: they showed ranging from $50 \%$ to $33 \%$ activity, for the applied doses, compared to indomethacin (100\%) and nontoxic at doses up to 160 $\mathrm{mg} / \mathrm{kg}$ [12]. Consequently, synthesis and biological screening of bearing selenium onto tetrahydroquinoline derivatives may discover new useful compounds for the treatment of inflammatory diseases and may act as drugs. In this paper we investigated selenophene and tetrahydroquinoline systems combined with a fused ring and screened these compounds for their inflammatory and analgesic effects.

\section{Results and discussion}

To attempt our target, we start with 2-oxo-4-(4-substituedphenyl)-1, 2, 5, 6, 7, 8-hexahydroquinoline-3-carbonitrile (5ac) which were prepared as according to known method

[1]. Reaction of $5 \mathrm{c}$ with $\mathrm{POCl}_{3}$ affording 2- Chloro-4-(4-methoxyphenyl)-5, 6, 7, 8-tetrahydro quinoline-3-carbonitrile (6) and reacted directly with sodium hydrogenselenide in ethanol to give 4-(4-methoxyphenyl)-5, 6, 7, 8tetrahydroquinoline-2 $(1 \mathrm{H})$ selenone-3-carbonitrile $(7)$.

Refluxing of compound 7 with chloro acetone or chloro acetonitrile or ethyl chloroacetate or chloro acetamide in ethanol in the presence of sodium acetate as a basic catalyst followed by sodium ethoxide afforded compounds 9 and 
11a-c respectively in excellent yields, via the intermediates 8 and 10a-c respectively. Furthermore reaction of compounds 11c with acetic anhydride, cyclohexanone and aromatic Aldehyde (anisaldehyde) gave the corresponding compounds 12, 13 and 14 respectively. The structures of the synthesized compounds were Characterized by their physical, analytical and spectral data.The results were displayed in (Table 1and 2).

Table 1: Physical Properties and Elemental Analyses of the New Compounds.

\begin{tabular}{|c|c|c|c|c|c|c|c|}
\hline \multirow{2}{*}{ Compd. } & \multirow{2}{*}{$\begin{array}{l}\text { Mp. }\left({ }^{\circ} \mathrm{C}\right) \\
\text { Yield (\%) }\end{array}$} & \multirow{2}{*}{$\begin{array}{l}\text { Formula } \\
\text { (Mwt) }\end{array}$} & \multirow{2}{*}{ Solvent of crystallization } & \multicolumn{4}{|c|}{ Analysis \% Calcd. (Found) } \\
\hline & & & & $\mathrm{C}$ & $\mathrm{H}$ & $\mathrm{N}$ & $\mathrm{Cl}$ \\
\hline $5 a$ & $290(90)$ & $\begin{array}{l}\mathrm{C} 17 \mathrm{H} 16 \mathrm{~N}_{2} \mathrm{O}_{2} \\
(280.32)\end{array}$ & Ethanol & $\begin{array}{l}72.84 \\
(72.66)\end{array}$ & $\begin{array}{l}5.75 \\
(5.68)\end{array}$ & $\begin{array}{l}9.99 \\
(9.79)\end{array}$ & \\
\hline $5 b$ & $260(85)$ & $\begin{array}{l}\text { C16H13CIN2O } \\
(284.74)\end{array}$ & Ethanol & $\begin{array}{l}67.49 \\
(67.20)\end{array}$ & $\begin{array}{l}4.60 \\
(4.50)\end{array}$ & $\begin{array}{l}9.84 \\
(9.66)\end{array}$ & $\begin{array}{l}12.45 \\
(12.30)\end{array}$ \\
\hline $5 c^{*}$ & 275 (reported) & $\begin{array}{l}\text { C16H14N2O } \\
(250.30)\end{array}$ & Ethanol & $\begin{array}{l}76.78 \\
(77.02)\end{array}$ & $\begin{array}{l}5.64 \\
(5.82)\end{array}$ & $\begin{array}{l}11.19 \\
(11.46)\end{array}$ & \\
\hline 6 & $170(85)$ & $\begin{array}{l}\text { C17H15CIN2O } \\
(298.77)\end{array}$ & Ethanol & $\begin{array}{l}68.34 \\
(68.11)\end{array}$ & $\begin{array}{l}5.06 \\
(4.88)\end{array}$ & $\begin{array}{l}9.38 \\
(9.11)\end{array}$ & $\begin{array}{l}11.87 \\
(11.75)\end{array}$ \\
\hline 7 & $190-192(70)$ & $\begin{array}{l}\text { C17H16N2OSe } \\
(343.28)\end{array}$ & Dioxane & $\begin{array}{l}59.48 \\
(59.22)\end{array}$ & $\begin{array}{l}4.70 \\
(4.65)\end{array}$ & $\begin{array}{l}8.16 \\
(8.00)\end{array}$ & \\
\hline 8 & $105-107(80)$ & $\begin{array}{l}\mathrm{C} 20 \mathrm{H} 20 \mathrm{~N} 2 \mathrm{O} 2 \mathrm{Se} \\
(399.34)\end{array}$ & Ethanol & $\begin{array}{l}60.15 \\
(60.00)\end{array}$ & $\begin{array}{l}5.05 \\
(4.89)\end{array}$ & $\begin{array}{l}7.01 \\
(6.88)\end{array}$ & \\
\hline 9 & $215-217(65)$ & $\begin{array}{l}\mathrm{C} 20 \mathrm{H} 20 \mathrm{~N} 2 \mathrm{O} 2 \mathrm{Se} \\
(399.34)\end{array}$ & $\mathrm{DMF} / \mathrm{H}_{2} \mathrm{O}$ & $\begin{array}{l}60.15 \\
(59.95)\end{array}$ & $\begin{array}{l}5.05 \\
(4.77)\end{array}$ & $\begin{array}{l}7.01 \\
(6.96)\end{array}$ & \\
\hline $10 \mathrm{a}$ & $194-196(75)$ & $\begin{array}{l}\text { C19H17N3OSe } \\
(382.32)\end{array}$ & Ethanol & $\begin{array}{l}59.69 \\
(59.61)\end{array}$ & $\begin{array}{l}4.48 \\
(4.19)\end{array}$ & $\begin{array}{l}10.99 \\
(10.74)\end{array}$ & \\
\hline $10 \mathrm{~b}$ & $145-146(55)$ & $\begin{array}{l}\mathrm{C} 21 \mathrm{H} 22 \mathrm{~N} 2 \mathrm{O} 3 \mathrm{Se} \\
(429.37)\end{array}$ & Ethanol & $\begin{array}{l}58.74 \\
(58.22)\end{array}$ & $\begin{array}{l}5.16 \\
(4.88)\end{array}$ & $\begin{array}{l}6.52 \\
(6.23)\end{array}$ & \\
\hline $10 \mathrm{c}$ & $\begin{array}{l}250-252 \\
(60)\end{array}$ & $\begin{array}{l}\mathrm{C} 19 \mathrm{H} 19 \mathrm{~N} 3 \mathrm{O} 2 \mathrm{Se} \\
(400.33)\end{array}$ & Ethanol & $\begin{array}{l}57.00 \\
(56.79)\end{array}$ & $\begin{array}{l}4.78 \\
(4.25)\end{array}$ & $\begin{array}{l}10.50 \\
(10.29)\end{array}$ & \\
\hline $11 \mathrm{a}$ & $>300(65)$ & $\begin{array}{l}\text { C19H17N3OSe } \\
(382.32)\end{array}$ & $\mathrm{DMF} / \mathrm{H}_{2} \mathrm{O}$ & $\begin{array}{l}59.69 \\
(59.48)\end{array}$ & $\begin{array}{l}4.48 \\
(4.32)\end{array}$ & $\begin{array}{l}10.99 \\
(10.89)\end{array}$ & \\
\hline $11 b$ & $\begin{array}{l}280-282 \\
(40)\end{array}$ & $\begin{array}{l}\mathrm{C} 21 \mathrm{H} 22 \mathrm{~N} 2 \mathrm{O} 3 \mathrm{Se} \\
(429.37)\end{array}$ & $\mathrm{DMF} / \mathrm{H}_{2} \mathrm{O}$ & $\begin{array}{l}58.74 \\
(58.46)\end{array}$ & $\begin{array}{l}5.16 \\
(5.00)\end{array}$ & $\begin{array}{l}6.52 \\
(6.34)\end{array}$ & \\
\hline $11 \mathrm{c}$ & $\begin{array}{l}270-272 \\
(55)\end{array}$ & $\begin{array}{l}\text { C19H19N3O2Se } \\
(400.33)\end{array}$ & $\mathrm{DMF} / \mathrm{H}_{2} \mathrm{O}$ & $\begin{array}{l}57.00 \\
(56.99)\end{array}$ & $\begin{array}{l}4.78 \\
(4.44)\end{array}$ & $\begin{array}{l}10.50 \\
(10.29)\end{array}$ & \\
\hline 12 & $>300(70)$ & $\begin{array}{l}\mathrm{C} 21 \mathrm{H} 19 \mathrm{~N} 3 \mathrm{O} 2 \mathrm{Se} \\
(424.35)\end{array}$ & $\mathrm{DMF} / \mathrm{H}_{2} \mathrm{O}$ & $\begin{array}{l}59.44 \\
(59.11)\end{array}$ & $\begin{array}{l}4.51 \\
(4.33)\end{array}$ & $\begin{array}{l}9.90 \\
(9.80)\end{array}$ & \\
\hline 13 & $>300(45)$ & $\begin{array}{l}\mathrm{C} 25 \mathrm{H} 27 \mathrm{~N} 3 \mathrm{O} 2 \mathrm{Se} \\
(480.46)\end{array}$ & $\mathrm{DMF} / \mathrm{H}_{2} \mathrm{O}$ & $\begin{array}{l}62.50 \\
(62.22)\end{array}$ & $\begin{array}{l}5.66 \\
(5.33)\end{array}$ & $\begin{array}{l}8.75 \\
(8.45)\end{array}$ & \\
\hline 14 & $>300(50)$ & $\begin{array}{l}\mathrm{C} 27 \mathrm{H} 25 \mathrm{~N} 3 \mathrm{O} 3 \mathrm{Se} \\
(518.47)\end{array}$ & $\mathrm{DMF} / \mathrm{H}_{2} \mathrm{O}$ & $\begin{array}{l}62.55 \\
(62.32)\end{array}$ & $\begin{array}{l}4.86 \\
(4.69)\end{array}$ & $\begin{array}{l}8.10 \\
(7.88)\end{array}$ & \\
\hline
\end{tabular}

Table 2: Physical Properties and Elemental Analyses of the New Compounds

\begin{tabular}{|c|c|c|}
\hline Compd. & $\operatorname{IR}\left(\mathrm{cm}^{-1}\right)$ & ${ }^{1} \mathrm{H}$ and ${ }^{13} \mathrm{C}-\mathrm{NMR}(\delta, \mathrm{ppm})$ \\
\hline $5 \mathrm{a}$ & $\begin{array}{l}3123(\mathrm{NH}), 2220 \\
(\mathrm{CN}), 1646(\mathrm{CO}) .\end{array}$ & $\begin{array}{l}\text { DMSO-d6 :1.55-2.55 (m, 8H, 4CH2); } 3.90\left(\mathrm{~s}, 3 \mathrm{H}, \mathrm{OCH}_{3}\right) ; 6.95-7.10(\mathrm{~m}, 4 \mathrm{H}, \mathrm{Ar}- \\
\mathrm{H}) ; 8.00(\mathrm{~s}, 1 \mathrm{H}, \mathrm{NH}) ; \\
{ }^{13} \mathrm{C}: 22.6,23.5,25.2,30.5\left(4 \mathrm{CH}_{2}\right) ; 55.5\left(\mathrm{OCH}_{3}\right) ; 115.3(\mathrm{C}-\mathrm{CN}) ; 115.9(\mathrm{CN}) ; 149.6 \\
(\mathrm{C} 4 \text {-quinoline }) ; 119.5(\mathrm{C} 5 \text {-quinoline }) ; 136.5(\mathrm{C} 6 \text {-quinoline }) ; 114.3,127.3,129.5 \text {, } \\
129.5,129.5,136.4(\mathrm{Ph}), 169.2(\mathrm{C}=\mathrm{O})\end{array}$ \\
\hline & & DMSO-d6 :1.60-2.55 (m, 8H, 4CH2); 7.20-7.30 (m, 4H, Ar-H); $8.00(\mathrm{~s}, 1 \mathrm{H}, \mathrm{NH})$ \\
\hline
\end{tabular}

$5 b$

$3190(\mathrm{NH}), 2220$

$(\mathrm{CN}), 1650(\mathrm{CO}$

$5 c^{*}$
DMSO-d6 :1.64-1.98 (m, 8H, 4CH2); 7.13-7.35 (m, 5H, Ar-H).8.10 (s, 1H, NH)

DMSO-d6 :1.55-2.55 (m, 8H, 4CH2); 3.90 (s, 3H, $\left.\mathrm{OCH}_{3}\right) ; 6.95-7.10$ (m, 4H, Ar-H)

DMSO-d6 :1.55-2.55 (m, 8H, 4CH2); 3.90 (s, 3H, $\left.\mathrm{OCH}_{3}\right)$; 6.95-7.10 (m, 4H, Ar$\mathrm{H}) ; 12.5(\mathrm{~s}, 1 \mathrm{H}, \mathrm{SeH})$

${ }^{13} \mathrm{C}: 22.6,23.5,25.2,30.5\left(4 \mathrm{CH}_{2}\right) ; 55.5\left(\mathrm{OCH}_{3}\right) ; 110.3(\mathrm{C}-\mathrm{CN}) ; 117.9(\mathrm{CN}) ; 149.6$ 


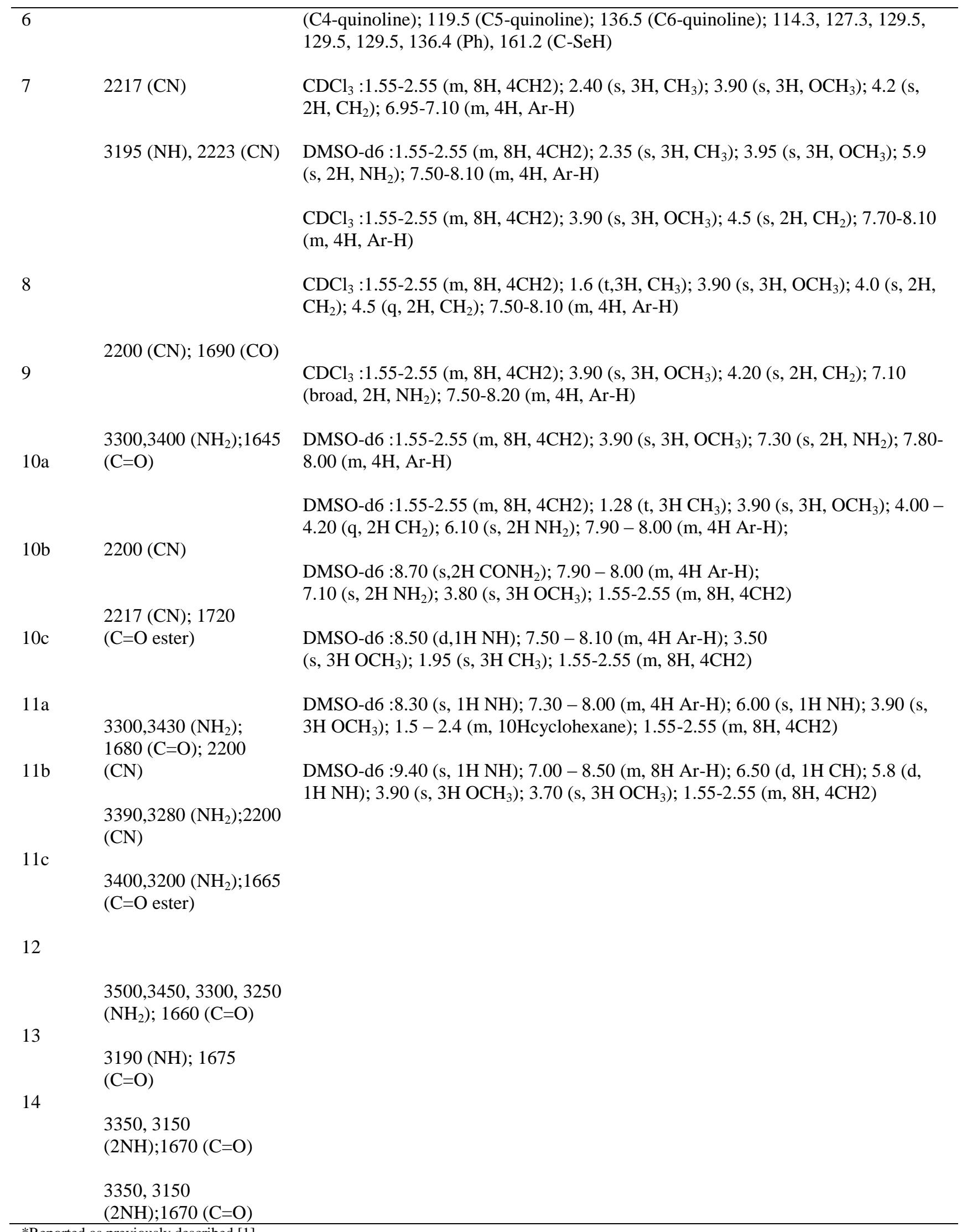




\section{Pharmacological results and discussion}

\subsection{Anti-inflammatory activity}

Anti-inflammatory activity of the tested synthesized compounds (5a-c, 7, 9, 11a-c, 12-14) was evaluated by carrageenan induced paw edema method of Winter et al [13]. The data are taken at 0.5,1,2,3,4 and 5h interval .The compounds were tested at doses of $10 \mathrm{mg} / \mathrm{kg}$.The results are listed in Table (3) and showed that after $3 \mathrm{~h}$ all the tested compounds gave inhibition activity against carrageenan -induced inflammation in rats. Compounds (5a, 7, 11c, 12 and 13) displayed strong activity and showed inhibition percentage ranged from (45.3-89\%) of that standard drug Indomethacin (100 \%), while after $5 \mathrm{~h}$ inhibition percentage ranged from (64.6-87.7\%). On the other hand, compounds (5c, 9 and $11 \mathrm{~b})$ showed moderate activity ranged from (40.6-50.2\%) less than of that Indomethacin. Finally, from the resulted data compounds (5b, 11a and 14) appeared weak activity with inhibition percentage ranged from (36.0-8.1\%). Generally, it was noticed that the tested synthesized compounds after $5 \mathrm{~h}$ interval and highly anti-inflammatory activity of the first group $7,11 \mathrm{c}$, 12 and 13 may be due to the presence of selenium and methoxyphenyl substituted in 4-postion in compound7 and the activity increased with selenium atom in cyclic structures.

\subsection{Analgesic activity}

The tested synthesized compounds (5a-c, 7, 9, 11a-c, 12-14) were tested for their analgesic properties relative to acetyl salicylic acid as reference drug at a dose level of $0.028 \mathrm{~mol} / \mathrm{kg}$ according to the reported procedures [14]. The results are given in (Table 4). The results showed that after $3 \mathrm{~h}$, compounds (5a, 7, 11c, 12 and 13) are the most active ranging from 60.4 to $112.3 \%$ compared to the reference drug, while compounds $5 \mathrm{c}$ and $11 \mathrm{~b}$ showed moderate activity with 45.6 $\%$ and $57 \%$ respectively compared to the reference drug. The rest compounds 5b 9, 11a and 14 showed very weak activity as compared the standard drug Aspirin. Generally, the most active inflammatory compounds gave the same trends as analgesic activity.

Table 4: Analgesic Activities of the Test Compound (On the Hot Plate)

\begin{tabular}{|c|c|c|c|c|c|c|}
\hline \multirow[b]{2}{*}{ Compound } & \multicolumn{6}{|c|}{ Time } \\
\hline & $0.5 \mathrm{~h}$ & $1 \mathrm{~h}$ & $2 \mathrm{~h}$ & $3 \mathrm{~h}$ & $4 h$ & $5 \mathrm{~h}$ \\
\hline $5 a$ & 20.8 & 29.1 & 32.3 & 26.6 & 23.2 & 20.1 \\
\hline $5 b$ & 5.1 & 5.9 & 6.7 & 4.5 & 4.2 & 4.0 \\
\hline $5 c$ & 14.9 & 19.5 & 20.5 & 16.6 & 15.8 & 15.2 \\
\hline 7 & 22.6 & 28.9 & 26.4 & 25.7 & 22.5 & 20.7 \\
\hline 9 & 9.4 & 13.6 & 15.2 & 10.0 & 9.7 & 8.6 \\
\hline $11 \mathrm{a}$ & 8.3 & 11.7 & 12.5 & 9.4 & 8.7 & 8.0 \\
\hline $11 \mathrm{~b}$ & 18.0 & 24.7 & 23.9 & 21.4 & 19.3 & 19.0 \\
\hline $11 \mathrm{c}$ & 31.7 & 43.5 & 49.5 & 45.0 & 38.7 & 33.8 \\
\hline 12 & 39.1 & 51.9 & 59.8 & 56.8 & 42.5 & 37.4 \\
\hline 13 & 29.8 & 41.4 & 46.3 & 39.9 & 33.8 & 30.3 \\
\hline 14 & 4.8 & 5.4 & 6.7 & 5.1 & 4.6 & 4.5 \\
\hline Control & 18.1 & 18.6 & 19.0 & 19.5 & 20.2 & 18.9 \\
\hline
\end{tabular}

\subsubsection{Acute toxicity (LD50)}

The median lethal dose $\left(\mathrm{LD}_{50}\right)$ of the most active inflammatory and analgesic compounds $(11 \mathrm{c}, 12$ and 13$)$ in addition compound 7 were determined (i.p) in mice according to reported procedures [15]. The animals got injection (i.p) of a certain grade. The results showed that the $\left(\mathrm{LD}_{50}\right)$ of tested compounds were non-toxic at doses up to $400 \mathrm{mg} / \mathrm{kg}$

\section{Experimental}

\subsection{General}

Melting points were determined by using the Kofler melting point apparatus, and were uncorrected. IR $\left(\mathrm{KBr}, \mathrm{cm}^{-1}\right)$ spectra were recorded on a Pye-Unicam SP3-100 instrument at Taif University. ${ }^{1} \mathrm{H}$ NMR spectra were obtained on a Varian (400 MHz) EM 390 USA instrument at Cairo University by using TMS as internal reference. 13C NMR spectra were recorded on a GEMINI-200 NMR200 at Cairo University. Elemental analyses were obtained on an Elementar Vario EL 1150C analyzer (Heraeus, Germany). Mass spectra were recorded on a JEOL-JMS-AX 500 at Cairo National Research Center, Cairo, Egypt. Purity of the compounds was checked by thin layer chromatography (TLC) using silica gel plates. 
2-Oxo-4-(4-substitutedphenyl)-1, 2, 5, 6, 7, 8-hexahydroquinoline-3-carbonitrile (5a-c), were prepared as according to previously procedure [1]. See physical properties and elemental analyses (Table 1). Also, IR, ${ }^{1} \mathrm{H}-$ and ${ }^{13} \mathrm{C}-\mathrm{NMR}$ of the new compounds $5 \mathrm{a}$ and $5 \mathrm{~b}$ and reported compound $5 \mathrm{c}$ (See Table 2).

2- Chloro-4-(4-methoxyphenyl)-5, 6, 7, 8-tetrahydroquinoline-3-carbonitrile (6)

A mixture of the corresponding 2-Oxo-4-(methoxyphenyl)-1, 2, 5, 6, 7, 8-hexahydroquinoline-3-carbonitrile derivative $5 \mathrm{a}(2.80 \mathrm{~g}, 10 \mathrm{mmol})$ and $\mathrm{POCl}_{3}(30 \mathrm{mmol})$ was refluxed for $3 \mathrm{~h}$ at $70^{\circ} \mathrm{c}$. The mixture was cooled and poured onto crushed ice. The solid precipitate was filtered, dried, and recrystallized from proper solvent.

4-(4-methoxyphenyl)-5, 6, 7, 8-tetrahydroquinoline-2(1H) selenone-3-carbonitrile (7)

A mixture of the corresponding chlorotetrahydroquinoline derivative 6 (2.99 g, $10 \mathrm{mmol})$, selenium metal (1.0 g, 12 $\mathrm{mmol})$ and sodium borohydride $(1.2 \mathrm{~g}, 32 \mathrm{mmol})$ was refluxed in ethanol $(50 \mathrm{~mL})$ for $6 \mathrm{~h}$. The mixture was cooled and poured in cold $\mathrm{HCl}$. The solid precipitate was filtered, dried, and recrystallized from proper solvent. Mass spectrum of compound.

7 exhibited molecular ion peak at $\mathrm{m} / \mathrm{z},(\%) 343(\mathrm{M}, 55 \%)$

3-Cyano-4-(4-methoxyphenyl)-2-substituted selenotetrahydroquinolines (8 and 10a-c)

General procedure:

A mixture of 7 (3.43 g, $10 \mathrm{mmol})$, fused sodium acetate $(0.98 \mathrm{~g}, 12 \mathrm{mmol})$, and chloroacetone chloroacetonitrile or ethyl chloroacetate or chloroacetamide $(12 \mathrm{mmol})$, respectively, in $30 \mathrm{~mL}$ ethanol was heated under reflux for $1 \mathrm{~h}$. The reaction mixture was allowed to cool and was then poured into $50 \mathrm{~mL}$ of ice water. The precipitate was collected by filtration and recrystallized from proper solvent.

3-Amino-2-acetyl-4-(methoxyphenyl) selenolo [2, 3-b]-5, 6, 7, 8-tetrahydroquinoline; 3-Amino-4-(4-methoxyphenyl) selenolo [2, 3-b]-5, 6, 7, 8-tetrahydroquinoline-2-carbonitrile;Ethyl- 3-Amino-4-(4-methoxyphenyl) selenolo [2, 3-b]-5, 6, 7, 8-tetrahydroquinoline-2-carboxylate; 3-Amino-4-(4-methoxyphenyl) selenolo $\quad[2, \quad 3-b]-5, \quad 6, \quad 7, \quad 8$ tetrahydroquinoline-2- carboxamide ( 9 and $11 \mathrm{a}-\mathrm{c})$

General procedure: Compounds 8 or $10 \mathrm{a}-\mathrm{c}(10 \mathrm{mmol})$ and EtONa $(0.5 \mathrm{~g}$. Na in $10 \mathrm{~mL}$ EtOH$)$ were refluxed for $10 \mathrm{~min}$. and then cooled. The solid product was collected and recrystallized from proper solvent.

Mass spectrum of compound 9 exhibited molecular ion peak at $\mathrm{m} / \mathrm{z},(\%) 399\left(\mathrm{M}^{+}, 65 \%\right)$

Mass spectrum of compound 11a exhibited molecular ion peak at $\mathrm{m} / \mathrm{z},(\%) 382\left(\mathrm{M}^{+}, 60 \%\right)$

Mass spectrum of compound 11 bexhibited molecular ion peak at m/z, (\%) $429\left(\mathrm{M}^{+}, 75 \%\right)$

Mass spectrum of compound 11c exhibited molecular ion peak at m/z, (\%) $400\left(\mathrm{M}^{+}, 100 \%\right)$

2-Methyl-4-(4-methoxyphenyl) pyrimido[4 ,5 : 4,5] selenolo[2,3-b]-5, 6, 7, 8-tetrahydroquinoline -11(1H)-one (12)

Compound 11c $(1.0 \mathrm{~g}, 25 \mathrm{mmol})$ and redistilled acetic anhydride $(20 \mathrm{~mL})$ were heated under reflux for $10 \mathrm{hrs}$, and then left to cool. The precipitate was filtered and crystallized from proper solvent. Mass spectrum of compound 12 exhibited molecular ion peak at $\mathrm{m} / \mathrm{z},(\%) 423\left(\mathrm{M}^{+}-1,50 \%\right)$

Spirocyclohexane-4-(4-methoxyphenyl)-3(H) pyrimido[4`5: 4,5]selenolo[2,3-b]-5, 6, 7, 8-tetrahydroquinoline 11(1H)-one; 2 (4`-methoxyphenyl)-4-(4-methoxyphenyl)-3(H) pyrimido[4 ,5 : 4,5]selenolo[2,3-b]-5, 6, 7, 8tetrahydroquinoline $-11(1 \mathrm{H})$-one (13 and 14)

General procedure: A mixture of $11 \mathrm{c}(1.0 \mathrm{~g}, 25 \mathrm{mmol})$ and the corresponding aromatic aldehyde or cyclohexanone (33 $\mathrm{mmol})$ was heated under reflux in glacial acetic acid $(20 \mathrm{~mL})$ for $5-7 \mathrm{~h}$, the solid was collected by filtration and recrystallized from acetic acid.

Mass spectrum of compound 13 exhibited molecular ion peak at m/z, (\%) $480\left(\mathrm{M}^{+}, 100 \%\right)$

Mass spectrum of compound 14 exhibited molecular ion peak at m/z, (\%) $518\left(\mathrm{M}^{+}, 70 \%\right)$

\section{Biological screening}

The biological screening was carried out at the Department of Biochemistry Faculty of Agriculture Cairo University, Giza, Egypt. Animals were obtained from the animal house of the Central Laboratory of Agricultural Pesticides, Dokki, Egypt. The experiments were performed with albino rats of wister strain of either sex, weighing (100-130g) .The animals were maintained at $25+2 \mathrm{C}$ and $50+2 \%$ relative humidity, $12 \mathrm{~h}$ light/ dark cycle .Food and water were freely available up to the time of experiments. The test compounds were dissolved in 1\% carboxy methyl cellulose (CMC) solution.

\subsection{Anti-inflammatory activity}

The anti-inflammatory of eleven synthesized compounds (5a-c,7,9,11a-c,12-14) were evaluated according to the method described by Winter et al [13], where a pedal inflammation in rat paws induced by sub-plantar injection of 0.2 $\mathrm{ml}$ carrageenan $(0.2 \%)$ suspension into the right hind of the rats. Male adult albino rats (100-130g) were divided into twelve groups, each of five animals. The thickness of rat paw was measured by a plethysmeter before and after $1 \mathrm{~h}$ of carrageenan injection to detect the inflammation induced by carrageenan. Test compounds at doses of $10 \mathrm{mg} / \mathrm{kg}$ were injected i.p to fifteen groups of rats $1 \mathrm{~h}$ after injection of carrageenan control group received the vehicle $(5 \%$ gum acacia), while reference group received Indomethacin at $10 \mathrm{mg} / \mathrm{kg}$. The difference between the thicknesses of two paws 
was taken as a measure of edema. The measurement was carried out at 0.5,1,2,3,4 and $5 \mathrm{~h}$, after injection of the test compounds, the reference drug and the vehicle. The percent of anti-inflammatory activity was calculated according to the formula given below. \% Anti-inflammatory activity $=\left(\mathrm{v}_{\mathrm{c}}-\mathrm{v}_{\mathrm{t}} / \mathrm{v}_{\mathrm{c}}\right) .100$, where $\mathrm{v}_{\mathrm{t}}$ represents the mean increase in paw volume in rats treated with the test compounds and $\mathrm{v}_{\mathrm{c}}$ represents the mean increase in paw volume in control group of rats. The results are displayed in Table 3.

Table 3: Inhibitory Effect of the Test Compounds and Indomethacin upon Carrageenan Induced Paw Edema in Rats (\% Edema Inhibition)

\begin{tabular}{|c|c|c|c|c|c|c|}
\hline \multirow[t]{2}{*}{ Compound } & \multicolumn{6}{|c|}{ Time } \\
\hline & $0.5 \mathrm{~h}$ & $1 \mathrm{~h}$ & $2 \mathrm{~h}$ & $3 \mathrm{~h}$ & $4 \mathrm{~h}$ & $5 \mathrm{~h}$ \\
\hline $5 a$ & 2.5 & 8 & 16.7 & 19.2 & 33.0 & 38.4 \\
\hline $5 b$ & 0.4 & 2.3 & 3.3 & 4.5 & 6.0 & 6.4 \\
\hline $5 c$ & 1.7 & 6.0 & 11.4 & 14.5 & 20.5 & 24.1 \\
\hline 7 & 2.7 & 8.8 & 18 & 22.7 & 31.8 & 40.5 \\
\hline 9 & 1.4 & 5.1 & 9.4 & 10.1 & 18.5 & 26.3 \\
\hline $11 \mathrm{a}$ & 1.0 & 4.0 & 8.2 & 9.3 & 19.8 & 21.4 \\
\hline $11 \mathrm{~b}$ & 2.2 & 7.4 & 14.8 & 17.9 & 24.1 & 29.8 \\
\hline $11 \mathrm{c}$ & 4.2 & 14 & 28.9 & 32.2 & 42.2 & 52.1 \\
\hline 12 & 4.7 & 14.8 & 30.6 & 37.9 & 48.5 & 50.3 \\
\hline 13 & 3.9 & 12.7 & 25.9 & 29.6 & 39.8 & 47.2 \\
\hline 14 & 0.5 & 2.6 & 3.1 & 4.2 & 5.1 & 4.8 \\
\hline Indomethacin & 6.1 & 19.3 & 32.2 & 42.4 & 52.0 & 59.4 \\
\hline
\end{tabular}

\subsection{Analgesic activity}

The analgesic activity of compounds (5a-c, 7, 9, 11a-c, 12-14) was determined in mice using the hot plate method [14] in comparison to Aspirin. In this method, the time taken by the mouse to lick its feet or to jump within a Plexiglas cylinder placed on a hot plate surface $\left(55^{\circ} \mathrm{c}\right)$ was determined. This reaction time was taken as the end point and the increase in hot plate latency was taken as a measure of the analgesic activity. Male adult albino mice (25-30 g) were divided into thirteen groups, each of five animals. Eleven test compounds and the reference drug were injected i.p. at dose level of $10 \mathrm{mg} / \mathrm{kg}$ into mice. Control group of animals was similarly treated with 5\% gum acacia .The reaction time was evaluated directly after $0.5,1,2,3,4$, and 5 h of injection. \% Analgesic activity $=\left(n^{-} n^{`} / n\right){ }^{-100}$; where $n `$ represents the mean number of writhes of the test compounds and $n$ represents the mean number of writhes of control group of rats .The results are displayed in (Table 4)

\subsection{Determination of acute toxicity (LD50)}

The median lethal dose $\left(\mathrm{LD}_{50}\right)$ of the test compounds were determined in mice .A group of male albino mice of five animals (25-30 g) was injected (i.p) at a certain grade. The percentage of mortality was determined $72 \mathrm{~h}$ after injection. Computation of $\mathrm{LD}_{50}$ was processed by a graphical method [15].

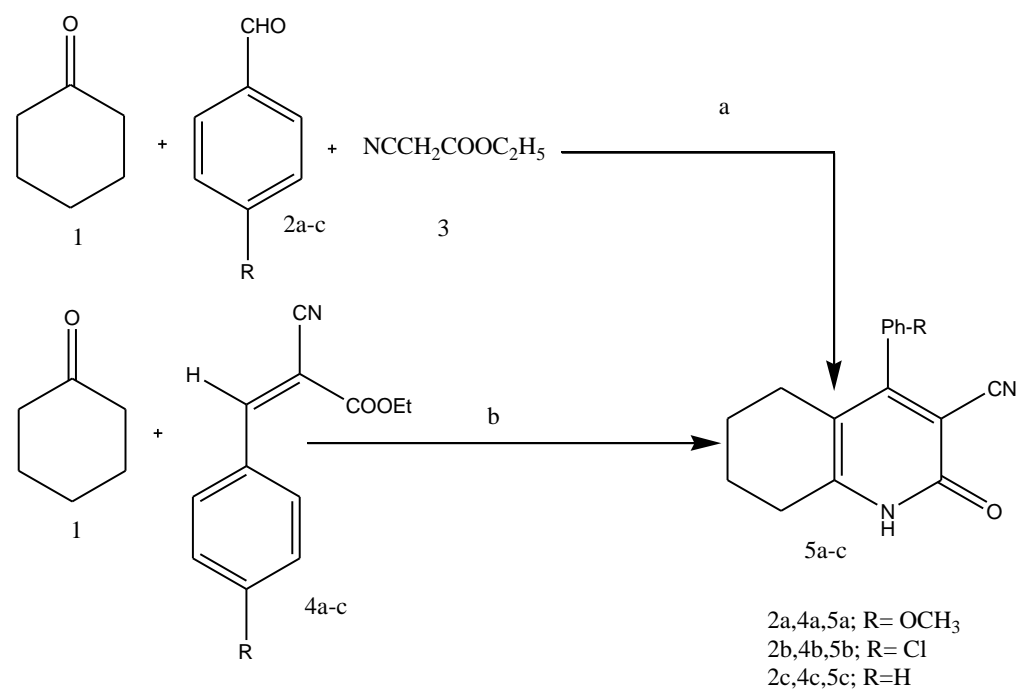

Scheme 1: a, $\mathrm{CH}_{3} \mathrm{COONH}_{4} / \mathrm{EtOH} / \mathrm{reflux} 30 \mathrm{hrs} ; \mathrm{b}, \mathrm{CH}_{3} \mathrm{COONH}_{4} / \mathrm{EtOH} / \mathrm{reflux}$ hrs 
<smiles>[Y]C(=O)COc1nc2c(c(-c3ccccc3)c1C#N)CCCC2</smiles>

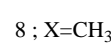<smiles>[X]C(=O)c1[se]c2nc3c(c(-c4ccccc4)c2c1N)CCCC3</smiles>

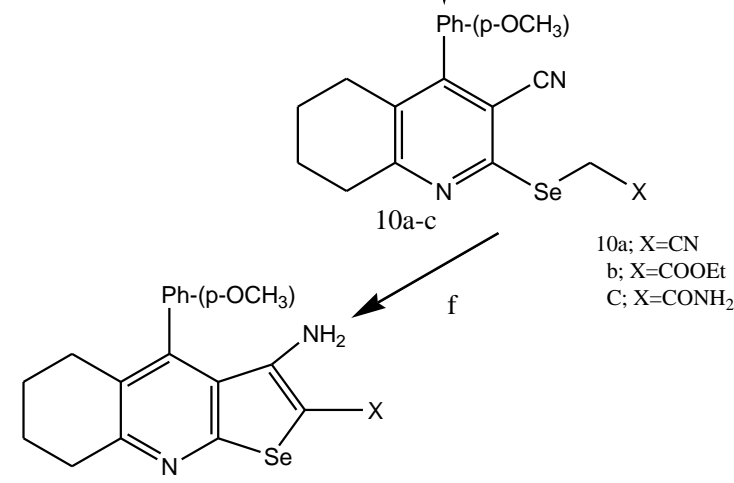

$9 ; \mathrm{X}=\mathrm{CH}_{3}$

$11 \mathrm{a}-\mathrm{c}$

$$
\text { 11a; } \mathrm{X}=\mathrm{CN}
$$

Scheme 2: a=POCl $/$ reflux 6 hrs; b=NaSeH/EtOH/reflux 3hrs; $\mathrm{C}=\mathrm{ClCH}_{2} \mathrm{COCH}_{3} / \mathrm{CH}_{3} \mathrm{COONa} / \mathrm{rflux} 1 \mathrm{hr}$; $\mathrm{d}=\mathrm{ClCH}_{2} \mathrm{X} / \mathrm{CH}_{3} \mathrm{COONa} /$ reflux $1 \mathrm{hr} ;$ e,f= $\mathrm{NaOEt} / \mathrm{EtOH} /$ freflux $1 \mathrm{hr}$.

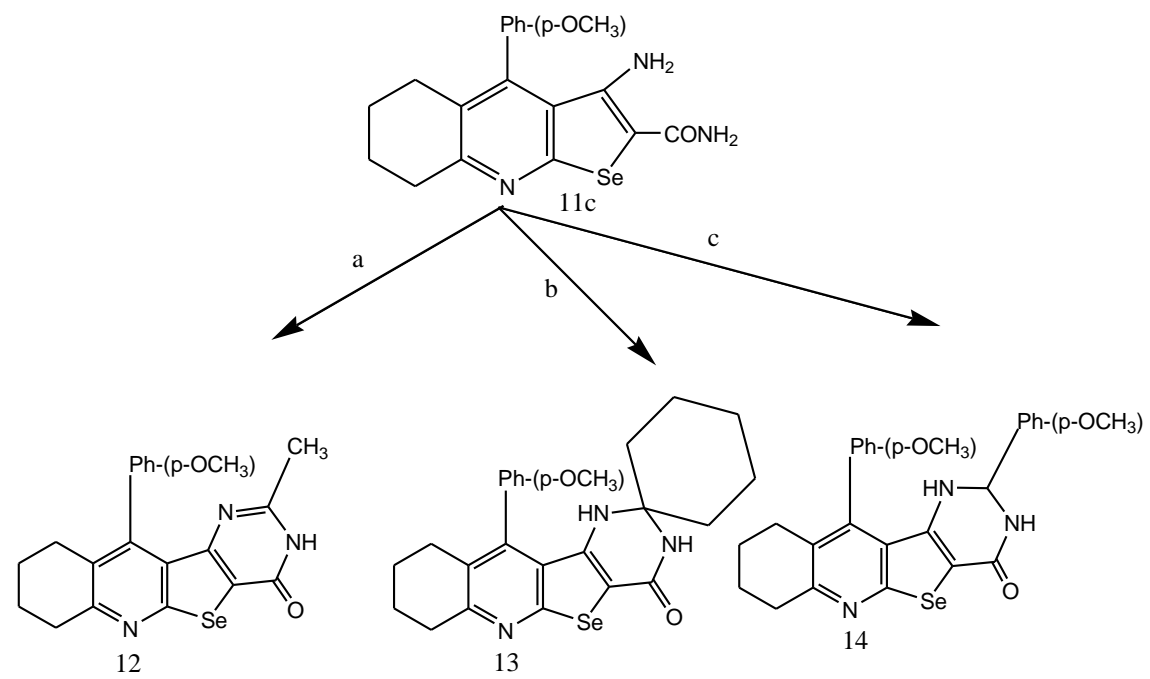

Scheme3: $\mathrm{a}=\mathrm{Ac}_{2} \mathrm{O} / \mathrm{reflux} / 10 \mathrm{hrs} ; \mathrm{b}=$ cyclohexanone/gl.acetic acid/reflux $6 \mathrm{hrs;}$ p-anisaldehyde/gl.acetic acid/reflux 6 hrs

\section{References}

[1] An Efficient Synthesis of Pyrazolo[3,4-b]quinolin-3-amine and Benzo[b][1,8]naphthyridine Derivatives, Yehya M. Elkholy, Molecules 2007, 12, 361-372. http://dx.doi.org/10.3390/12030361.

[2] Reaction of 3-aminocyclohex-2-en-1-ones with arylidenemalononitriles: synthesisof $\mathrm{N}$ substituted 1, 4, 5, 6, 7, 8- hexahydroquinolin-5onesLichitsky, B. V., Dudinov, A. A.; Krayushkin, M. M. Arkivoc 2001,73-79.

[3] The synthesis of 4-aryl-1H-pyrazolo [3, 4-b] quinolines by cyclization of 4 arylidenepyrazolin-5-ones with anilinesChaczatrian, K.; Chaczatrian, G.; Danel, A.; Tomasik P. Arkivoc 2001, 63-69.

[4] An efficient synthesis of benzo[b] [1,8]naphthyridine-3-carboxylic methyl esters (pages 755-758) Nithyadevi V.; Rajendran, S. P.J. Heterocycl. Chem. 2006, 43, 755-758. http://dx.doi.org/10.1002/jhet.5570430334 
[5] Synthesis of 4-azido-3-diazo-3 H-pyrazolo [3, 4-b] quinoline from 3-amino-4-hydrazino-1 H-pyrazolo [3, 4-b] quinoline 1, W Stadlbauer, G Hojas the Chemical Society, Perkin Transactions 1, 2000 -, 3085-3087.

[6] Facile Synthesis of 5, 6, 7, 8-Tetrahydropyrimido [4, 5-b]-quinoline Derivatives Elkholy, Y. M.; Morsy, M. A. Molecules 2006, 11, 890-903. http://dx.doi.org/10.3390/11110890.

[7] A NEW APPROACH TO THE SYNTHESIS OF BENZO[b][1,8]NAPHTHYRIDIN-I(IH)ONESVijayalakshmi, S.; Ragunath, L.; Rajendran, S. P. A, Heterocycl. Commun. 2001, 7, 177-182.

[8] Synthesis and Antimicrobial Activity of Novel Pyrazolo[3,4-b]quinoline Derivatives El-Sayed, O. A.; Aboul-Enein, H. Y. Arch. Pharm. (Weinheim) 2001, 334, 117-120. http://dx.doi.org/10.1002/1521-4184 (200104)334:4<117: AID-ARDP117>3.0.CO; 2-9.

[9] Analogues of 1-(3, 10-dibromo-8-chloro-6, 11-dihydro-5H-benzo-[5, 6]-cyclohepta [1, 2-b] pyridin-11-yl)piperidine as inhibitors of farnesyl protein transferase.Wolin, R.; Wang, D., Kelly, J.; Afonso, A.; James, L.; Kirschmeier, P.; Mcphail, A. T. Bioorg. Med. Chem. Lett. 1996, 6, 195- 200.

[10] 1-substituted, 3-carboxy, 7-fluoro,8-disubstituted amino-1,4-dihydrobenzo(b)(1,8)naphthyridin-4-ones; Useful as antimicrobial agents; topical antibiotic for wounds Antoine, M.; Barreau, M.; Descon, C.; Philippe, G.; Guy, P.US Pat. 6548506, 2003

[11] An Efficient Synthesis of Pyrazolo [3, 4-b] quinolin-3-amine and Benzo [b] [1, 8] naphthyridine Derivatives YM Elkholy - Molecules, 2007.

[12] Selenium-Containing Heterocycles: Synthesis and Pharmacological Activities of Some New 4-Methylquinoline-2(1H) Selenone Derivatives (pages 240-246) Shams H. Abdel-Hafez, Mostafa A. Hussein, Arch. Pharm. Chem. Life Sci. 2008, 341, 240 - 246. http://dx.doi.org/10.1002/ardp.200700202.

[13] Carrageenin-induced edema in hind paw of the rat as an assay for antiiflammatory drugsWinter, C.A., Risley, E.A.G.A.N. Nus Proc. Soc. Exp.Biol.111 (1962) 544-547. http://dx.doi.org/10.3181/00379727-111-27849.

[14] Acetic acid for analgesic screening Koster, R. Anderson, M. De Beer, E.J. Fed.Proc. 18 (1959) 412.

[15] Sztaricskai, F. Takacs, I.E. Pusztai, F. Szabo, G., Csipo, I., Phosphorus Sulfur,Silicon Relat. Elem. 332 (1999) 321-326. 